\title{
The acceptance of blockchain technology in meat traceability and transparency
}

Citation for published version (APA):

Sander, F., Semeijn, J., \& Mahr, D. (2018). The acceptance of blockchain technology in meat traceability and transparency. British Food Journal, 120(9), 2066-2079. https://doi.org/10.1108/BFJ-07-2017-0365

Document status and date:

Published: 01/01/2018

DOI:

10.1108/BFJ-07-2017-0365

Document Version:

Publisher's PDF, also known as Version of record

Document license:

Taverne

Please check the document version of this publication:

- A submitted manuscript is the version of the article upon submission and before peer-review. There can be important differences between the submitted version and the official published version of record.

People interested in the research are advised to contact the author for the final version of the publication, or visit the DOI to the publisher's website.

- The final author version and the galley proof are versions of the publication after peer review.

- The final published version features the final layout of the paper including the volume, issue and page numbers.

Link to publication

\footnotetext{
General rights rights.

- You may freely distribute the URL identifying the publication in the public portal. please follow below link for the End User Agreement:

www.umlib.nl/taverne-license

Take down policy

If you believe that this document breaches copyright please contact us at:

repository@maastrichtuniversity.nl

providing details and we will investigate your claim.
}

Copyright and moral rights for the publications made accessible in the public portal are retained by the authors and/or other copyright owners and it is a condition of accessing publications that users recognise and abide by the legal requirements associated with these

- Users may download and print one copy of any publication from the public portal for the purpose of private study or research.

- You may not further distribute the material or use it for any profit-making activity or commercial gain

If the publication is distributed under the terms of Article $25 \mathrm{fa}$ of the Dutch Copyright Act, indicated by the "Taverne" license above, 
$\mathrm{BFJ}$

120,9

\section{6}

Received 24 August 2017 Revised 5 March 2018 18 March 2018 Accepted 19 March 2018

\section{The acceptance of blockchain technology in meat traceability and transparency}

\author{
Fabian Sander \\ School of Business and Economics, Maastricht University, \\ Maastricht, The Netherlands \\ Janjaap Semeijn \\ Department of Marketing and SCM, School of Business and Economics, \\ Maastricht University, Maastricht, The Netherlands, and \\ Dominik Mahr \\ School of Business and Economics, Service Science Factory, Maastricht University, \\ Maastricht, The Netherlands
}

\begin{abstract}
Purpose - The purpose of this paper is to investigate meat traceability by outlining the different perspectives and opinions of meat supply chain stakeholders (SCSs); it also evaluates potential of acceptance of blockchain technology (BCT) as a viable transparency and traceability system (TTS).

Design/methodology/approach - A questionnaire survey of 141 consumers reveals their opinions about TTSs. In addition, semi-structured interviews with seven retail managers, four government officials and one blockchain service provider (Project Provenance Ltd) provide expert insights.

Findings - The results demonstrate that consumers are overwhelmed by the amount and complexity of certification labels. As a TTS, BCT implementation appears to have significant positive influences on consumers' purchasing decisions, mediated by consumers' quality perceptions. This study reveals the discordant perspectives of different stakeholders with regard to the importance of a BCT-based TTS.

Originality/value - This study investigates current TTSs and certification labels, and probes customer perception of a potential BCT-based solution for meat traceability. Changes to supply chains' mentality and the active establishment of trust in BCT applications are needed. Firms should take both holistic and altruistic views to deal with the challenges of TTSs in the meat supply chain. The adoption of BCT, in combination with DNA coding, seems promising as a solution to many of the issues that currently plague TTSs.
\end{abstract}

Keywords Transparency, Purchasing decision

Paper type Research paper

\section{Introduction}

Over the past decade, a series of meat scandals in Europe (e.g. 2013 horse meat scandal, 2008 Irish pork crisis) has highlighted the importance of meat safety and quality regulations for consumers. Brazil's meat scandal of early 2017 had a dramatic impact on the European Union also, as the EU is the largest importer of Brazilian poultry (Bloomberg, 2017). Such crises also reiterate the need for traceability and transparency systems (TTSs) in food supply chains.

In response, this paper proposes a potential solution to traceability issues in the meat supply chain (e.g. window dressing, information fraud): the service innovation of blockchain technology (BCT) (Kumar, 2016; Lemieux, 2016). This decentralized, online ledger aims to facilitate peer-to-peer transactions and ease traceability by securely storing information that has been approved by all connected parties (Kumar, 2016; Lemieux, 2016). Due to the fact that $\mathrm{BCT}$ is at a very early stage of development, no uniform definition does exist, yet (Lemieux, 2016). Condos et al. (2016) define BCT as an electronic ledger for digital data sets, events or transactions, which are governed via the participants of a widespread computer network.

This study represents the first empirical attempt to evaluate the potential of a TTS based on BCT from a holistic perspective including all related supply chain stakeholders (SCSs) 
(i.e. farmers, butchers, retailers, consumers, government officials and third-party transparency service providers (3pTSP)). Previous studies have established the requirements of a complete and credible TTS but failed to link these features to BCT, despite the clear match of characteristics (Kassahun et al., 2014; Trienekens et al., 2011). Furthermore, most meat traceability studies are relatively outdated and conducted in the USA in the early 2000s without touching upon the proposed link to BCT (e.g. Dickinson and von Bailey, 2002; Verbeke and Ward, 2006).

By investigating existing TTSs (i.e. certification labels) and the potential role of BCT as a TTS, according to different SCSs in the meat industry, this in-depth investigation offers a holistic picture of the various perspectives involved and thus enhances the awareness of BCT as a TTS, such that it may serve as a basis for its future development and discussion. The analysis of the complexity of BCT also may help supply chain managers understand its spectrum, potential and role as a TTS in meat supply chains. This paper addresses the overall research question - what factors related to consumers and other supply chain stakeholders determine the acceptance of blockchain technology function as a transparency and traceability system in meat supply chains? - this study relies on one consumer survey and 12 semi-structured interviews conducted with SCSs in the meat industry. This mixed method approach combines quantitative generalization with qualitative in-depth understanding of the relevant meat SCSs.

Section 2 thus contains an overview of existing literature, which provides the foundation for the hypotheses. After a description of the methodology in Section 3, Section 4 details the analysis. Finally, this paper concludes with a discussion and some managerial implications.

\section{Literature review}

This paper focuses mainly on the traceability of meat products, which also reflects the supply chain's transparency. Dickinson and von Bailey (2002, p. 1) define meat traceability as the "ability to trace the retail meat back to the farm or [the] animal of origin" and transparency as "knowing the meat was produced without added growth hormones, or knowing the animal was humanely treated."

\subsection{Supply chain issues}

According to Trienekens et al. (2011), current systems cannot guarantee the integrity of information or the transparency needed to ensure food quality and safety. In an early proposition of the alternative of a cloud-based service as a solution, Kassahun et al. (2014) suggest that the access and controllability associated with cloud-based IT might help facilitate information sharing and traceability processes for food. Although, they do not mention BCT explicitly, the system that Kassahun et al. describe matches the characteristics of BCT: independent and decentralized, with complete and credible information provision.

The EU Commission's Beef Labeling Regulation 1760/2000 was introduced and made compulsory for all EU member states in July 2000. This law requires correct information labeling for meat, starting with the quartering process for beef at the abattoir and up until the final packaging at the selling point (GS1 Ireland, 2005). This tracing system is the most advanced in the EU, yet it still features major flaws. First, imports from other continents are not taken into account and remain hard to regulate. Second, there are several weak links in the information sharing chain. Especially between farmer and abattoir, no mechanism ensures the credibility of the shared information (Pardo et al., 2015). Third, human error and active information manipulation remain ever-present issues.

Pardo et al. (2015) also emphasize that companies must acknowledge that today's consumers have become a lot more sophisticated and knowledgeable about the products they purchase. Thus, credible transparency appears inevitable. In a globalized world, where imports and exports are common practice, a global TTS across borders is critical.
Blockchain technology

2067 
$\mathrm{BFJ}$ 120,9

\subsection{Origin and potential of $B C T$}

$\mathrm{BCT}$ deals with similar transparency and traceability challenges. Its peer-to-peer structure facilitates any type of transaction (e.g. physical assets, money, intellectual property), without mediation. Yet, its security and trustworthiness are established by a decentralized, cloud-based, independent protocol. The parties involved in a transaction must approve the transfer process online. The information gets saved securely in a digital ledger, which exists on all related parties' computers simultaneously, such that it literally is impossible to change any information. Over time, all transactions of an asset get recorded and locked into decentralized digital blocks, which, combined, form an asset-specific online information chain (Kumar, 2016; Lemieux, 2016; Twesige, 2015). Accordingly, BCT is easily accessible, transparent and highly distributed (Twesige, 2015). It provides a decentralized, highly secure platform, which is independent and accessible to any connected actor.

In comparison, other technologies such as radio-frequency identification (RFID) require physical sensors, attached to the product itself. As items travel through detection gates, their route can be traced by the product's sensor. These applications for livestock might provide better traceability in the beef industry, though sensors can easily get lost or purposely removed (Feng et al., 2012; Chao et al., 2007). In addition, no independent control mechanism or institution regulates the proper and truthful usage of RFID tags. Tian (2016) links RFID to BCT.

A more advanced method relies on DNA barcoding. When the animal is slaughtered, its DNA-ID can be indicated on the product packaging, which, in theory, allows tracing it back to its origin. While this method is technical feasible, unfortunately, this approach again lacks trustworthiness, due to the absence of any verification or control systems (Clark, 2015). Both ID tags and DNA codes can be manipulated and altered without anyone noticing. Nevertheless, DNA barcoding could be a useful supplement, in combination with BCT.

\subsection{Application of BCT as a TTS}

Despite the clear need for transparency, traceability and information sharing in meat supply chains (Kassahun et al., 2016; Pant et al., 2015), extant literature is remarkably silent with regard to BCT in this context. In its early stages, BCT is slowly being adopted as a TTS for consumer goods, and quite a few service providers already provide some off-the-shelf BCT traceability solutions. For the sake of simplicity, this paper refers to them as 3pTSP. Kassahun et al. (2014) propose that 3pTSPs are relevant for developing proper transparency in meat supply chains, in that they provide a means to base TTSs on cloud-based solutions. These external systems and providers help ensure independence, integrity and credibility. While current technologies would enable BCT solutions, implementation barriers exist in the compatibility of systems across the supply chain, the resistance of change among actors, information overload and distribution of costs. Other industries already overcame some of these BCT obstacles such as the finance industry when implementing Bitcoin and smart contract solutions.

\subsection{Research questions and hypotheses}

According to label-online.de, the European Union currently maintains 58 food- and beverage-specific quality labels. In addition, each nation has its own unique food quality labels. At the time of writing, Germany had 92 national food quality labels, beyond the 58 labels required by the European Union. Wu et al. (2011) identify the lack of consumer familiarity with certified traceable food, along with the doubt that consumers' sense about the function of certification labels in general. One reason for this confusion could be the vast number and complexity of available certification labels (Gellynck et al., 2006). 
For example, the pork industry has been criticized for regularly employing gene feeding and antibiotics (Silbergeld et al., 2008). However, virtually no livestock or farming conditions are communicated to the final customers through pork certification labels. Providing consumers with a tool to explore meat products' origin, easily and by themselves should create an environment of trust. In particular, providing consumers with self-led investigation tools could eradicate uncertainty about meat production conditions:

$R Q 1$. How are current TTSs in the meat sector viewed by consumers?

H1a. The numerical overload and complexity of certification labels have negative effects on consumers' trust in origin claims.

H1b. Consumers' knowledge about and familiarity with meat certification labels have positive effects on consumers' trust in origin claims.

H1c. Access to self-led investigation tools has positive effects on consumers' trust in origin claims.

Pardo et al. (2015) propose that consumers' quality perception diminish in response to false label information on food products. Thus, a possible link arises between TTSs and customers' ultimate quality perception of food produce. Those quality perceptions, in turn, affect purchasing decisions (Grunert et al. 2004). Vukasovič (2009) also notes that a major influence on the purchase decision process is knowledge about the origin of the meat. Unlike conventional systems though, TTSs could be linked to quality perceptions by providing integrated, vivid information exchanges among all supply chain actors (Trienekens et al., 2011). By definition, BCT ensures this capability:

$R Q 2$. How and to what extent view consumers BCT as a traceability and transparency instrument in meat supply chains?

H2a. BCT implementation as a TTS in food supply chains has a positive effect on consumers' quality perceptions.

H2b. BCT implementation as a TTS in food supply chains has a positive effect on consumers' purchasing decisions.

H2c. Consumers' quality perceptions have positive effects on their purchasing decisions.

However, various SCSs have different interests in relation to traceability and transparency, such that certain characteristics will not be equally important to all stakeholders (Wiese and Toporowski, 2013). According to Mai et al. (2010), even the quantifiable benefits of TTSs are perceived differently by SCSs in the food supply chain. We propose the following hypothesis:

H3. Due to varying stakeholder interests, BCT implementation as a TTS is not equally important to all participants of the meat supply chain.

Finally, the stakeholder theory holds that a firm's performance depends on its ability to manage its relationships with all its stakeholders (Okpara and Idowu, 2013). Therefore, it is of utmost importance to take all stakeholders' opinions into account to derive a feasible, effective solution for meat traceability. This study considers a four-echelon supply chain (i.e. cattle farm, butcher, retailer and consumer), as well as the perspectives of the government and 3pTSPs as an overarching interest group.

\section{Methodology}

To test the hypotheses empirically, an online questionnaire was sent via e-mail to approximately 500 meat consumers, and 212 participated in the survey. However,

Blockchain technology 
$\mathrm{BFJ}$

120,9

2070

71 incomplete/irrelevant responses and outliers had to be removed, resulting in a final sample size of 141 respondents. The questionnaire was distributed through the online service qualtrics.com, which applied convenience sampling. It also was distributed deliberately to various age groups, to establish a representative sample. The descriptive statistics for this consumer survey are in Table I, revealing a fairly well-mixed sample, other than a slight majority of young respondents (21-35 years, 60.3 percent) with a low-end income (less than $€ 15,000,72.3$ percent). The consumers in our sample are omnivores, consume meat several times a week, and shop for meat at the supermarket and purchase organic foods with moderate frequency. Respondents related their food retail products of their choice where certification labels can apply. We refrained from asking about specific supply chains because consumers often lack such in-depth information.

The survey also contained reverse-coded questions to reduce the threat of biases. An introductory page clarified key terms and concepts, such as traceability, transparency and BCT. Most of the questionnaire items were adopted or adapted from existing research in the field of traceability and transparency in the meat industry (Gellynck et al., 2006; Rijswijk van et al., 2008). Using a five-point Likert scale $(1=$ "highly disagree" to $5=$ "highly agree"), consumers indicated their perceptions and opinions about the current certification label system, as well as their expectations and views of a complete, BCT-based TTS. The data were statistically analyzed using SPSS and Smart PLS, and the statistical output is detailed in Section 4. Regarding non-response bias, a comparison of the first 30 responses with the last 30 responses submitted revealed no significant differences.

To support this research and the survey findings, the authors also conducted semistructured interviews with seven retail managers in Germany and the Netherlands (AH, Jumbo, Aldi, Lidl, EDEKA, REWE, Real), four government officials (Germany, the Netherlands, Belgium) and one 3pTSP (Great Britain). The interviews were conducted in person, with the exception of the government representatives, due to their schedules and time constraints. The interview questions were based on the consumer survey and adapted to the respective SCS, gathering these respondents' opinions about current certification label systems, how they anticipate TTSs will evolve in the future and their thoughts on a BCT-based solution. The interviews help complete the holistic picture by including all relevant stakeholder groups and enrich the discussion regarding BCT-based TTSs in the meat industry.

The consumers and retailers represented two cities, one in Germany and one in the Netherlands. After making contact with eight consumer rights and health ministers (in Belgium, Germany and the Netherlands), four agreed to provide written statements in response to the developed interview questions. Among four main blockchain 3pTSPs, one (Project Provenance Ltd) agreed to a face-to-face interview.

The survey and interview questions were distributed in English and German, to reach a wide pool of participants. A pilot group of five participants served to validate and carefully pre-test the questionnaire and interview questions. After multiple revisions and editing, the final survey and interview protocols were sent to the respective SCSs.

The test of the reliability and validity of the data set relied on the Cronbach's $\alpha$ values for the items in each construct; all these values were above the 0.6 threshold (Sekaran and Bougie, 2013). Furthermore, the relations between the constructs in the proposed research framework were validated by Pearson's correlation (Table II), which indicates a significant linear correlation between the respective constructs. These further confirm the significant findings detailed in Figure 1. Finally, the average variance extracted values in Table II are greater than the 0.6 threshold, with the exception of the second construct: "knowledge and familiarity about certification labels." 


\begin{tabular}{|c|c|c|c|}
\hline Characteristics & Frequency $(n=141)$ & $\%$ & $\begin{array}{l}\text { Blockchain } \\
\text { technology }\end{array}$ \\
\hline $\begin{array}{l}\text { Gender } \\
\text { Male } \\
\text { Female } \\
\text { Total }\end{array}$ & $\begin{array}{r}56 \\
85 \\
141\end{array}$ & $\begin{array}{r}39.7 \\
60.3 \\
100.0\end{array}$ & \\
\hline $\begin{array}{l}\text { Age } \\
\text { Under } 20 \\
21-35 \\
36-50 \\
51-65 \\
66 \text { or older } \\
\text { Total }\end{array}$ & $\begin{array}{r}10 \\
85 \\
22 \\
15 \\
9 \\
141\end{array}$ & $\begin{array}{r}7.1 \\
60.3 \\
15.6 \\
10.6 \\
6.4 \\
100.0\end{array}$ & 2071 \\
\hline $\begin{array}{l}\text { Net income } \\
\text { Under } 15,000 \\
15,001-45,000 \\
45,001 \text { or higher } \\
\text { Total }\end{array}$ & $\begin{array}{r}102 \\
25 \\
14 \\
141\end{array}$ & $\begin{array}{r}72.3 \\
17.8 \\
9.9 \\
100.0\end{array}$ & \\
\hline $\begin{array}{l}\text { Education level } \\
\text { Elementary School } \\
\text { High School } \\
\text { Undergraduate (i.e. Bachelor) } \\
\text { Postgraduate (i.e. Master) } \\
\text { Doctoral or equivalent } \\
\text { Total }\end{array}$ & $\begin{array}{r}1 \\
60 \\
62 \\
16 \\
2 \\
141\end{array}$ & $\begin{array}{r}0.8 \\
42.6 \\
43.9 \\
11.3 \\
1.4 \\
100.0\end{array}$ & \\
\hline $\begin{array}{l}\text { Frequency of organic meat pur } \\
\text { Exclusively } \\
\text { Very often } \\
\text { Often } \\
\text { Rarely } \\
\text { Never } \\
\text { Total }\end{array}$ & $\begin{array}{r}2 \\
23 \\
71 \\
45 \\
0 \\
141\end{array}$ & $\begin{array}{r}1.4 \\
16.3 \\
50.3 \\
32.9 \\
0.0 \\
100.0\end{array}$ & \\
\hline $\begin{array}{l}\text { Place of meat purchase } \\
\text { Discounter } \\
\text { Supermarket } \\
\text { Local butcher } \\
\text { Organic specialty store } \\
\text { Farmers Market } \\
\text { I do not consume meat } \\
\text { Total }\end{array}$ & $\begin{array}{r}13 \\
72 \\
36 \\
5 \\
2 \\
13 \\
141\end{array}$ & $\begin{array}{r}9.2 \\
51.1 \\
25.5 \\
3.6 \\
1.4 \\
9.2 \\
100.0\end{array}$ & \\
\hline $\begin{array}{l}\text { Frequency of meat consumptio } \\
\text { Daily } \\
\text { Several times a week } \\
\text { Once a week } \\
\text { Less than once a week } \\
\text { Total }\end{array}$ & $\begin{array}{r}20 \\
69 \\
31 \\
21 \\
141\end{array}$ & $\begin{array}{r}14.3 \\
48.9 \\
21.9 \\
14.9 \\
100.0\end{array}$ & \\
\hline $\begin{array}{l}\text { Type of food consumer } \\
\text { Omnivore } \\
\text { Vegetarian } \\
\text { Vegan } \\
\text { Total }\end{array}$ & $\begin{array}{r}122 \\
13 \\
6 \\
141\end{array}$ & $\begin{array}{r}86.5 \\
9.2 \\
4.3 \\
100.0\end{array}$ & $\begin{array}{r}\text { Table I. } \\
\text { Demographic details } \\
\text { of the consumer } \\
\text { sample }\end{array}$ \\
\hline
\end{tabular}


BFJ
120,9

2072

\section{Results}

\subsection{Survey}

By entering the final data set and corresponding model into Smart PLS, the analysis produced $R^{2}$ values, path coefficients and the respective $t$-values, according to the partial least squares algorithm and bootstrapping method (Figure 1).

Figure 1 shows possible variables that might influence consumers' trust in origin claims, representing $\mathrm{H} 1 \mathrm{a}-\mathrm{H} 1 \mathrm{c}$ (right-hand side of Figure 1), and the impact of a BCT implementation as a TTS, representing $H 2 a-H 2 c$ (left-hand side of Figure 1). As this figure reveals, only the overload and complexity of certification labels has a significant negative impact on consumers' trust in origin claims, in support of $H 1 a(\alpha \leqslant 0.05)$ but not $H 1 b$ or $H 1 c$. The relationship between access to self-led investigation tools and consumers' purchasing decision appears highly significant $(\alpha \leqslant 0.01)$. Moreover, BCT implementation as a TTS exhibits high significance for both consumers' quality perceptions and their purchasing decisions, in support of the need for a complete, credible TTS, which BCT can facilitate (Lemieux, 2016). In addition, consumers' quality perceptions exert highly positive, significant effects on consumers' purchasing decisions. A mediation analysis tests whether consumers' quality perception (Q) acts as a mediator between BCT implementation as a TTS (I) and consumers' purchasing decisions (P). The Sobel test produces a statistical value of

Table II.

Means, standard deviations, reliabilities and correlations

\begin{tabular}{|c|c|c|c|c|c|c|c|c|c|c|c|c|}
\hline Variables & AVE & Mean & SD & $n$ & 1 & 2 & 3 & 4 & 5 & 6 & 7 & 8 \\
\hline $\begin{array}{l}\text { 1. Overload and complexity of } \\
\text { certification marks }\end{array}$ & 0.835 & 3.53 & 0.99 & 141 & 0.69723 & & & & & & & \\
\hline $\begin{array}{l}\text { 2. Knowledge and familiarity } \\
\text { about certification marks }\end{array}$ & 0.308 & 2.09 & 0.72 & 141 & -0.153 & 0.0949 & & & & & & \\
\hline 3. Access to self-investigation tools & 0.699 & 3.94 & 0.75 & 141 & $0.212^{\star \star}$ & 0.029 & 0.4886 & & & & & \\
\hline 4. Consumer's trust in origin claims & 0.720 & 3.28 & 0.87 & 141 & $-0.224^{\star \star \star}$ & 0.075 & -0.127 & 0.5184 & & & & \\
\hline 5. Consumer's quality perception & 0.712 & 3.73 & 0.84 & 141 & -0.021 & -0.147 & 0.118 & 0.041 & 0.50694 & & & \\
\hline 6. Customer's purchasing decision & 0.898 & 3.98 & 0.85 & 141 & $0.166^{\star \star}$ & 0.027 & $0.406^{\star \star \star}$ & 0.048 & $0.341^{\star \star \star}$ & 0.8064 & & \\
\hline $\begin{array}{l}\text { 7. BCT implementation as a TTS } \\
\text { (consumers) }\end{array}$ & 0.826 & 4.43 & 0.74 & 141 & 0.131 & -0.149 & $0.379^{\star \star \star}$ & 0.049 & $0.327^{\star \star \star \star}$ & $0.369^{\star \star \star \star}$ & 0.6823 & \\
\hline $\begin{array}{l}\text { 8. BCT implementation as a TTS } \\
\text { (meatproducers) }\end{array}$ & 0.720 & 4.18 & 0.83 & 30 & -0.223 & 0.16 & -0.282 & -0.161 & -0.206 & -0.26 & -0.108 & 0.518 \\
\hline
\end{tabular}

Notes: AVE, average variance extracted. correlations. $* * * * *$ Significant at $0.1,0.05$ and 0.01
Figure 1.

Path coefficients and $t$-values (in brackets)

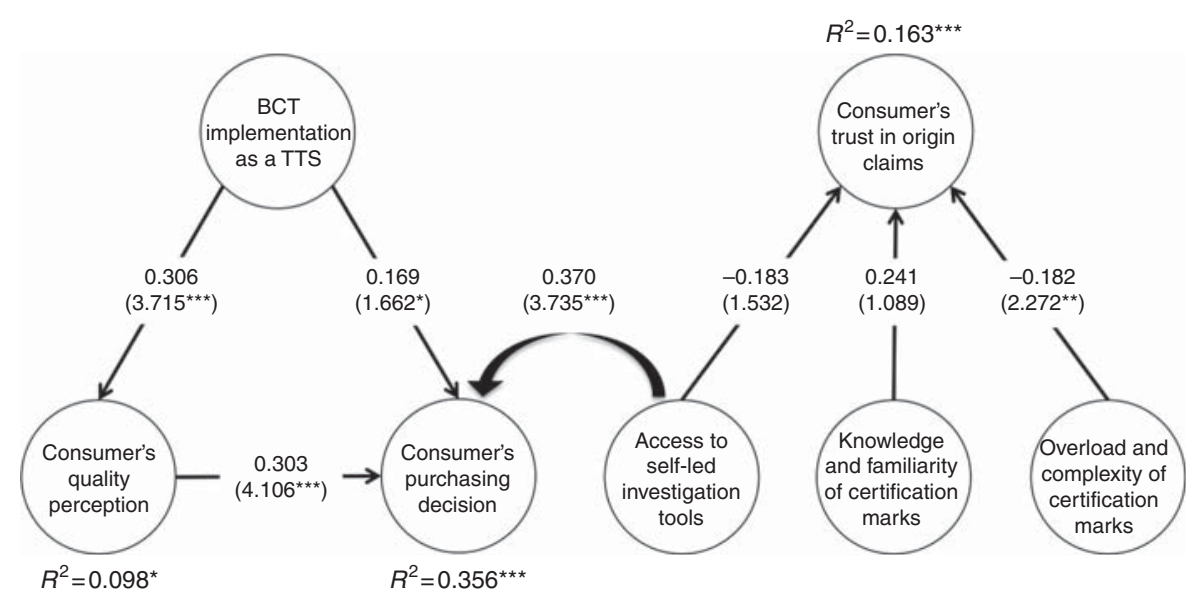

Notes: $*, * *,{ }^{* * *}$ Significant at $0.1,0.05$ and 0.01 
2.592, suggesting this mediation is significant with a two-tailed probability of 0.009 . Thus, the construct $\mathrm{Q}$ acts as a mediator between I and $\mathrm{P}$, offering support for $H 2 a-H 2 c$. The statistical value of the Sobel test has been computed by SPSS. Finally, the $R^{2}$ value associated with consumers' purchasing decisions indicates that 35.6 percent $(\alpha \leqslant 0.01)$ of the variance can be explained by a BCT-based TTS, the resulting quality perceptions and access to self-led investigation tools (bold arrow in Figure 1) as one of the major features of BCT.

\subsection{Interviews}

In general, the interviewed retail managers indicate that consumers have not articulated sufficiently strong demand for a complete TTS. Instead, they perceive consumers as rather price conscious:

- "Consumer demand for a complete transparent traceability system is not high enough to justify the implementation of such a system. The consumer does not care until a scandal is uncovered" (Retail Manager 1).

- "20 per cent of consumers would like to have complete transparency, and 80 per cent do not demand such a system" (Retail Manager 2).

- "The consumer has sufficient information on the packaging, such as country of origin" (Retail Manager 4).

Government officials' main concern about a complete TTS is the financial burden and who will bear the costs of such a supply chain-wide system:

- "[Complete TTSs are a] matter of cost and benefit. Identification systems, which are on a free-choice basis, offer the possibility to satisfy the demand for information [by the consumer]" (Government Representative 2).

However, the greatest cost factor associated with a complete TTS based on BCT would be the initial setup costs. Once process changes have been undertaken and the BCT infrastructure has been established, the actual maintenance and running costs would be similar to those of the internet to its users (Kumar, 2016).

The retailers also noted openly that their franchisors and management had intentions to engage in window dressing:

- "Supermarkets invest in transparency systems because of their image and reputation” (Retail Manager 3).

The government officials expressed concern about the complexity of the ingredients of some food products. As the list of compositions in a food product grows, so does the difficulty of tracing the sources of all its ingredients:

- "The more complex the composition of a food product is, the more problematic it gets for businesses to gather and provide correct information [for the consumer]" (Government Representative 1).

Currently, few supply chains actually implement BCT. The interviewed 3pTSP highlights the need for trust, to familiarize stakeholders with the concept and its potential for enhancing their business and consumption practices:

- "There is a need to establish trust and understanding for TTSs based on BCT with all stakeholders. It will take time to successfully tackle this challenge. The consumer has not been shown the potential, risks and reality of supply chains related to BCT" (3pTSP).

Government officials openly stated the need to communicate the true meaning of certification labels in more depth. Furthermore, the interview with one of the chair

Blockchain technology 
$\mathrm{BFJ}$

120,9

2074

members of The Hague's Dutch Authority for Consumers and Markets referred to one of its own studies:

- "[Our study] revealed that consumers have trouble grasping the true significance of individual certification labels. Consumers have difficulties telling the difference between trustworthy labels and a mere marketing gimmick, [which] hurts the credibility of trustworthy labels" (Government Representative 3).

Finally, implementing TTSs throughout the entire supply chain requires a change in mindset:

- "The motivation differs from level to level, and there is a need for a mentality revolution toward a common goal of branding and marketing" (3pTSP).

- "A mentality in supply chains for open and transparent production needs to be created in order for a TTS, for example based on BCT, to evolve and being implemented" (3pTSP).

In addition, one retailer suggested seeking a compromise:

- "A way in-between seems to be reasonable. No transparency at all is not good, but having a complete TTS is not economic and feasible either" (Retail Manager 7).

Related to this perception is the concept of benefits for early adopters:

- "Early adopters of BCT in the meat industry can be very successful. Especially, with the combination of DNA codification" (Project Provenance Ltd).

According to the 3pTSP, this combination of BCT and DNA coding offers the best potential for a sophisticated, complete TTS for meat supply chains. The DNA coding ensures that the information gathered is truly related to a specific animal and its origin.

\subsection{Comparison of different SCS perspectives}

The summary in Table III is based on the surveys and interviews. It shows that among the various SCSs, different concerns and issues arise, depending on their stage and role in the meat supply chain.

These results offer qualitative support for $H 3$; the different stakeholder groups disagree on several aspects. Consumers are overwhelmed by the current certification systems and would take a complete TTS, such as one based on BCT, into careful consideration for their final purchasing decisions and related quality perception. In contrast, supply chain businesses tend to participate in TTSs merely for reputational advantages or to comply with laws and regulations. In addition, meat providers articulate their beliefs that the consumer mainly cares about price, rather than truthful information, though this situation tends to persist only until scandals materialize (e.g. BSE, or "mad cow disease," in the 1990s). However, consumers' information and safety concerns tend to fade relatively quickly (Vassilikopoulou and Stavroulakis, 2013). Government officials cited concerns related to costs and feasibility. In addition, they seem confident that current TTSs fulfill customers' needs sufficiently. In contrast, Wognum et al. (2010) assert that governments have a responsibility to stimulate cooperation and networks in industries, to encourage traceability and transparency.

\section{Discussion}

\subsection{Aligning the findings with BCT characteristics}

The findings derived from this research, centered on the concerns articulated by meat SCSs, can be addressed by the functions that BCT offers. The consumer data clearly show that consumers are overwhelmed by the current certification system, in which labels are hard to understand and distinguish in terms of their relevance and credibility (Gellynck et al., 2006). 
Stakeholder

group Perspective and opinion

Consumer Overwhelmed by current certification mark system Supports $H 1 a$ and $H 3 a-H 3 c$

$(n=141) \quad$ Perceive enhanced quality perception, which, in turn, influences their purchasing decision, based on the existence of a complete TTS

Supply chain producers $(n=30)$

Majority of customers care mainly about the price Current systems often boost company reputation Neither extreme: total neither transparency nor traceability, at all, are desirable: a compromise of both is needed

Government Concerned about who will bear the costs and the officials $(n=4)$ actual magnitude of the financial burden

Doubt about feasibility of complete transparency and traceability

Tends to have the opinion that the current systems are sufficient, but that the true significance of individual certification labels needs to be better communicated

3pTSPs $(n=1)$ Change in mentality of the SCSs is required first See the need to build trust with SCSs regarding BCT Early adopter potential by combining BCT and DNA identification
Integration into research model

Positive link between BCT as a TTS

and consumer's quality perception and their final purchasing decision Support for $\mathrm{H} 2 a$ and $H 2 b$

Contradicts the findings of the consumer survey, which indicates an endorsement for improving TTS ( $\mathrm{Hla}$ and $H 3 a-H 3 c)$

Government is the only SCS that directly articulated concerns regarding costs and feasibility. Feasibility is confuted among others by successful projects by "Project Provenance Ltd." Contradicts the belief of consumers, as they feel overwhelmed by the current TTS in place (i.e. certification marks) The 3pTSP proves the issue identified in this research: there is a need for a census across the meat supply chain, and establishment of trust in BCT
Table III.

Summary of different perspectives of the SCSs

By offering a standardized, decentralized platform, BCT overcomes this issue by providing easy access that enables consumers to investigate a product's origin and trace it through the supply chain by themselves (Tian, 2016).

Both the interview data from the government officials and Wognum et al. (2010) emphasize the challenge of collecting relevant data to facilitate complete transparency and traceability in current systems. However, a standardized, holistic, digital, online system could solve these problems, assuming every supplier keeps its data up to date. Possible legal sanctions for meat producers could help ensure that they provide complete information. Trienekens et al. (2011) also assert that for traceability and transparency in food supply chains to work, web-based network applications and integrated databases, as functions of information systems, are required. These are the exact characteristics of BCT (Kumar, 2016; Lemieux, 2016).

However, government officials expressed doubts regarding the financing of such systems and their feasibility. They also articulated the position that every actor is responsible at its stage of the supply chain. Thus, the main challenge will be to ensure the participation of large meat providers that compete on a cost base, as they are unlikely to have an interest in sharing their information about how their animals have been farmed, slaughtered and processed. Governments must step in to enforce complete and continuous information sharing across all supply chain actors. Protocol standards and DNA coding promise great value for facilitating this process (Clark, 2015). Overall, such efforts can increase fair competition and create a transparent marketplace in which consumers see and understand what they are purchasing (James, 2013). If meat producers are afraid to put their cards on the proverbial table, then it is a clear sign that it is time for a change - in both the mentality of the supply chain and the way it produces meat.

\subsection{Answers to the research questions}

Regarding the role of current TTSs in the meat sector, the findings clearly show that consumers experience numerical and complexity overloads when it comes to certification labels, which decrease their trust in origin claims on meat products. They struggle to 
$\mathrm{BFJ}$

120,9

2076

evaluate all the different labels, and eventually, they seem to base their decisions on price rather than quality or origin. The access to self-led investigation tools would be highly welcomed by these shoppers and would influence their purchasing decision. The different SCSs offer distinctive opinions though; some meat providers openly regard transparency and traceability mechanisms as pure window dressing activities, without perceiving any consumer demand for improved, more sophisticated systems. Government officials confirmed that the lack of proper communication about the meaning and significance of certification labels is an issue. The 3pTSP also expressed concern about the credibility and reliability of existing TTSs. Hence, current TTSs need to undergo a significant amount of change to better address the information needs of consumers and enhance the accuracy of the information collected across the supply chain. Policy makers seem to be most suited, together with consumer association, to initiate these changes.

In terms of the extent to which BCT can serve as a traceability and transparency instrument in meat supply chains, the findings further show that consumers would value a TTS based on BCT, reflecting the positive relation between a complete TTS and consumers' quality perception and purchasing decisions. Similarly, Mai et al. (2010) find that complete traceability results in improved product quality. Additionally, Vukasovič (2009) indicates that knowing the origin of meat produce has a key influence on consumers' purchasing decision process. Thus, the call for self-led investigation tools could be satisfied with a BCT system in place.

Trust in BCT and a better understanding of its potential must be established before meat supply chains will even start considering implementing this technology. Along similar lines, Mattevi and Jones (2016) show that many food producers have only a limited understanding of the definition of TTSs.

The insights related to these research questions reflect and inform the main research goal: How can BCT function as a TTS in meat supply chains? First, end customers would value BCT, because BCT's consumer-friendly capability allows consumers to investigate origin claims on their own. This can enhance customers' educated purchasing decision and resolve the problem of being overwhelmed by the massive amount of certification labels. Second, particularly in combination with DNA coding, BCT offers characteristics and a platform that can facilitate a digital, independent, decentralized online ledger that guarantees both credibility and reliance.

\section{Managerial implications}

This analysis clearly identifies the need to revise current TTSs because the average consumer seems overwhelmed by the complexity of available certification labels. Because these customers also appear to base their quality perceptions and purchasing decisions on the availability of a complete TTS, members of the meat supply chain should consider the application of BCT. In doing so, businesses should adopt an altruistic attitude and be responsive to stakeholders' articulated preferences (Okpara and Idowu, 2013). There is a clear need to form a census and shift the mentality in the meat supply chain. The meatsupplying firms bear the responsibility to facilitate this change, and to function as change agents and role models, due to their helicopter perspective on the supply chain (Buchanan and Boddy, 1992).

Many current issues associated with traceability and transparency in meat supply chains could be effectively overcome and mitigated by BCT (e.g. accurate information transfer, consumer-friendly access to traceability, cost reductions by eliminating mediators). In particular, the combination of a BCT-based TTS with DNA coding could provide nearly perfect assurance for the provenance information of meat products. Meat providers should seriously rethink their way of doing business and information sharing methods; as this research shows, a complete TTS positively affects perceived quality and purchasing 
decisions among customers. Admittedly, such a radical change might be too disruptive for most organizations, so it requires highly skilled management and change agents (Davenport, 1998). Thus, a phasing strategy to implement BCT in meat supply chains is recommended (Brown et al., 2009).

\section{Conclusion}

This paper provides a holistic picture of the current status associated with the potential adoption of BCT in the meat supply chain. Considering the need to establish trust for any such radical change in technology, this study undertook an academic analysis of the different perspectives of various meat SCSs. Their opinions about and perceptions of TTSs in the meat industry diverge, which might be the reason current systems have stagnated in their evolution. Consumers are overwhelmed by the current certification system, yet their quality perceptions and purchasing decisions would depend strongly on a complete TTS based on BCT, if it were to exist. Moreover, DNA coding can enrich the beneficial features of $\mathrm{BCT}$, namely, ensuring credible and reliable product information through the entire meat supply chain, from farm to fork.

Nonetheless, further, more in-depth, research should be conducted, as this paper provides merely a snapshot of a single meat supply chain as well as a limited number of insights by general SCSs. Additionally, future research should investigate whether there is a significant difference in importance to the final consumer between different types of food produce (e.g. dairy products, fruits, vegetables).

The need for a change in mentality throughout the entire supply chain is especially pertinent on the business side. Supply chains must think more holistically and altruistically, regarding transparency and traceability as a requirement, not a choice. Currently, BCT is still in its early stages and needs more time to achieve full acceptance, application and potential. The finance sector is already close to being conquered by $\mathrm{BCT}$, and it may be just a matter of time before other industries, such as the meat sector, will follow.

\section{Reference}

Bloomberg (2017), "Brazil's biggest meat buyers restrict supplies after tainted food scandal", available at: www.bloomberg.com/news/articles/2017-03-20/global-meat-buyers-restrict-brazil-suppliesas-scandal-deepens (accessed March 21, 2017).

Brown, C.V., DeHayes, D.W., Hoffer, J.A., Wainright, M.E. and Perkins, W.C. (2009), "Methodologies for custom software development", in Yagan, S. and Svendsen, E. (Eds), Managing Information Technology, Pearson Education, Prentice Hall, Upper Saddle River, NJ, pp. 375-396.

Buchanan, D. and Boddy, D. (1992), The Expertise of the Change Agent, Prentice Hall, London.

Chao, C.C., Yang, J.M. and Jen, W.Y. (2007), "Determining technology trends and forecasts of RFID by a historical review and bibliometric analysis from 1991 to 2005", Technovation, Vol. 27 No. 9, pp. 268-279.

Clark, L.F. (2015), "The current status of DNA barcoding technology for species identification in fish value chains", Food Policy, Vol. 54 No. 5, pp. 85-94.

Condos, J., Sorrell, W.H. and Donegan, S.L. (2016), "Blockchain technology: opportunities and risks", Vermont, Vol. 1 No. 1, pp. 1-35.

Davenport, T.H. (1998), "Putting the enterprise into the enterprise system”, Harvard Business Review, Vol. 4 No. 1, pp. 121-131.

Dickinson, D.L. and von Bailey, D. (2002), "Meat traceability: are U.S. consumers willing to pay for it?", Journal of Agricultural and Resource Economics, Vol. 27 No. 2, pp. 348-364.

Feng, J., Fu, Z., Wang, Z., Xu, M. and Zhang, X. (2012), "Development and evaluation on a RFID-based traceability system for cattle/beef quality safety in China", Food Control, Vol. 31 No. 10, pp. 314-325. 
$\mathrm{BFJ}$ 120,9

Gellynck, X., Verbeke, W. and Vermeire, B. (2006), "Pathways to increase consumer trust in meat as a safe and wholesome food", Meat Science, Vol. 74 No. 5, pp. 161-171.

Grunert, K.G., Bredahl, L. and Brunsø, K. (2004), "Consumer perception of meat quality and implications for product development in the meat sector - a review", Meat Science, Vol. 66 No. 2 , pp. 259-272.

GS1 Ireland (2005), Beef Traceability Case Study, GS1 Ireland, Dublin.

James, H.S. (2013), The Ethics and Economics of Agrifood Competition, The International Library of Environmental, Agricultural and Food Ethics, Springer, Columbia.

Kassahun, A., Hartog, R.J.M. and Tekinerdogan, B. (2016), "Realizing chain-wide transparency in meat supply chains based on global standards and a reference architecture", Computers and Electronics in Agriculture, Vol. 123 No. 3, pp. 275-291.

Kassahun, A., Hartog, R.J.M., Sadowski, T., Scholten, H., Bartram, T., Wolfert, S. and Beulens, A.J.M. (2014), "Enabling chain-wide transparency in meat supply chains based on the EPCIS global standard and cloud-based services", Computers and Electronics in Agriculture, Vol. 109 No. 10, pp. 179-190.

Kumar, V. (2016), "New kid on the blockchain”, Focus Blockchain, Vol. 8 No. 3, pp. 19-22.

Lemieux, V.L. (2016), “Trusting records: is blockchain technology the answer?", Records Management Journal, Vol. 26 No. 2, pp. 110-139.

Mai, N., Bogason, S.G., Arason, S., Árnason, S.V. and Matthíasson, T.G. (2010), "Benefits of traceability in fish supply chains - case studies", British Food Journal, Vol. 112 No. 9, pp. 976-1002.

Mattevi, M. and Jones, J.A. (2016), "Food supply chain - are UK SMEs aware of concept, drivers, benefits and barriers, and frameworks of traceability?", British Food Journal, Vol. 118 No. 5, pp. 1107-1128.

Okpara, J.O. and Idowu, S.O. (2013), Corporate Social Responsibility. Challenges, Opportunities and Strategies for 21st Century Leaders, Springer-Verlag, Heidelberg.

Pant, R.R., Prakash, G. and Farooquie, J.A. (2015), “A framework for traceability and transparency in the dairy supply chain networks", Social and Behaviorial Sciences, Vol. 189 No. 1, pp. 385-394.

Pardo, M.A., Jiménez, E. and Pérez-Villarreal, B. (2015), "Misdescription incidents in seafood sector", Food Control, Vol. 62 No. 11, pp. 277-283.

Rijswijk van, W., Frewer, L.J., Menozzi, D. and Faioli, G. (2008), “Consumer perceptions of traceability: a cross-national comparison of the associated benefits", Food Quality and Preference, Vol. 19 No. 10 , pp. $452-464$.

Sekaran, U. and Bougie, R. (2013), Research Methods for Business: A Skill-Building Approach, 6th ed., Wiley, New York, NY.

Silbergeld, E.K., Graham, J. and Price, L.B. (2008), "Industrial food animal production, antimicrobial resistance, and human health", Annual Review of Public Health, Vol. 29 No. 4, pp. 151-169.

Tian, F. (2016), An Agri-Food Supply Chain Traceability System for China Based on RFID \& Blockchain Technology, Department of Information Systems and Operations, Vienna University of Economics and Business, Vienna.

Trienekens, J.H., Wognum, P.M., Beulens, A.J.M. and van der Vorst, J.G.A.J. (2011), "Transparency in complex dynamic food supply chains”, Advanced Engineering Informatics, Vol. 26 No. 2012, pp. 55-65.

Twesige, R. (2015), "Bitcoin: a simple explanation of bitcoin and block chain technology", Computer Science, Vol. 1 No. 1, pp. 1-5.

Vassilikopoulou, A. and Stavroulakis, P.J. (2013), "The impact of time on product-harm crises in the food industry: the case of IKEA's meatballs", Recent Techniques in Educational Science, Vol. 1 No. 1, pp. 135-140.

Verbeke, W. and Ward, R.W. (2006), "Consumer interest in information cues denoting quality, traceability and origin: an application of ordered probit models to beef labels", Food Quality and Preference, Vol. 17 No. 7, pp. 453-467. 
Vukasovič, T. (2009), "Consumer perception of poultry meat and the importance of country of origin in a purchasing making process", World's Poultry Science Journal, Vol. 65 No. 1, pp. 65-74.

Wiese, A. and Toporowski, W. (2013), "CSR failures in food supply chains - an agency perspective", British Food Journal, Vol. 115 No. 1, pp. 92-107.

Wognum, P.M., Bremmers, H., Trienekens, J.H., van der Vorst, J.G.A.J. and Bloemhof, J.M. (2010), "Systems for sustainability and transparency of food supply chains - current status and challenges", Advanced Engineering Informatics, Vol. 25 No. 10, pp. 65-76.

Wu, L., Xu, L. and Gao, J. (2011), "The acceptability of certified traceable food among Chinese consumers", British Food Journal, Vol. 113 No. 4, pp. 519-534.

\section{Corresponding author}

Fabian Sander can be contacted at: fabian-sander@outlook.com

For instructions on how to order reprints of this article, please visit our website: 